REPORTS OF MORPHOLOGY
Official Journal of the Scientific Society of Anatomists,
Histologists, Embryologists and Topographic Anatomists
of Ukraine
journal homepage: https://morphology-journal.com

\title{
Electronic microscopic research on periodont in experimental two- weight opioid action and after its over for four weeks
}

Fik V.B. ${ }^{1}$, Paltov Ye.V. ${ }^{1}$, Kryvko Yu. Ya. ${ }^{2}$

${ }^{1}$ Danylo Halytsky Lviv National Medical University, Lviv, Ukraine

2Higher Educational Communal Institution of Lviv Regional Council "Andrey Krupynsky Lviv Medical Academy", Lviv, Ukraine

\section{ARTICLEINFO}

Received: 22 June, 2019

Accepted: 23 July, 2019

UDC: 611.311-018.73:615.214.24:616076.4

\section{CORRESPONDING AUTHOR}

e-mail: fikvolodymyr@ukr.net Fik V.B.

\begin{abstract}
Due to the harmful effects of opioid agents in the uncontrolled use of them, it is impossible to ease the early manifestations of damage to the tissues and organs of the oral cavity, which is a pressing problem of today. The purpose of this work was to investigate the features of the sub-microscopic organization of the structural components of the periodontium under the action of an opioid analgesic for two weeks and its fourweek withdrawal in the experiment. The study was conducted on 22 adult rats-males of the Wistar line, weighing $160 \mathrm{~g}$, 4.5-6 months of age. Animals were administered intramuscularly daily, once a single opioid analgesic nalbuphine for the first two weeks, in terms of the mean therapeutic dose for the rat, as well as for the mean weight of the test group $(0.212 \mathrm{mg} / \mathrm{kg})$, and subsequent four weeks. The fragments of soft periodontal tissue were used for electron microscopic examination. Submicroscopically expressed destructive changes in periodontal tissues were not observed. However, the positive dynamics of regeneration of periodontal components at the ultrastructural level were also not revealed. In the cytoplasm of cells of the epithelium of the free part of the gums, there is destruction of organelles, partially damaged mitochondrial cristae, poorly contoured tonofilaments, shallow karyolemma invaginations, thickened areas and damaged desmosomal contacts. In the surface areas of the periodontium, the collagen fibers are partially stratified, there is moderate swelling of the intercellular substance of the connective tissue, part of the fibrocytes invaginating the karyolemma of the nucleus and placement of heterochromatin in the periphery. Ultrastructurally in the cytoplasm of the macrophage, lysosomes are detected, phagosomes are scarce, indicating a slight damage to the structures. In the gaps of the blood capillaries, blood cells are formed, mainly erythrocytes, in the perinuclear part of the cytoplasm of organelles are few, mitochondria with electron-light matrix and small cristae, perivascular edema is insignificant, there are destructively altered mitochondria in the cytoplasm of endothelial cells of venules, the basement membrane is thickened, the perivascular spaces are enlarged. Thus, at the end of the sixth week of the experiment, no shortterm irreversible changes in the ultrastructural organization of the periodontal components were detected in the short-term effect of the opioid for two weeks and its subsequent four-week cancellation. However, the complete restoration of the structural components of the periodontium is not observed, there are signs of reactive changes, reparative processes are slowed.

Keywords: periodontium, opioid, abolition of the opioid, ultrastructure, experiment.
\end{abstract}

\section{Introduction}

The tissues and organs of the oral cavity are especially responsive to any harmful stimuli in the body $[9,18,26]$. Under the influence of factors of exogenous origin disturbances of gums resistance arise, which causes pathological changes in periodontium tissues [14, 19]. It should be noted that periodontium diseases and gums bleeding are more common in drug abusers compared to the general population $[10,20,21,25]$. Important are the issues of therapeutic tactics of inflammatory periodontal diseases in drug addicts, as well as the abolition of the drug, which is necessary for both local and general action on the tissues of the periodontal complex [5, 6, 16, 21, 23]. However, the mapping of the pathomorphological pattern in periodontal tissues is a rather complicated process and 
changes in this case occur over a period of time with the involvement of different mechanisms of pathogenesis [3, 7]. Therefore, experimental studies related to the study of the ultrastructural organization of the periodontium and the correction of pathological changes that occur during the action of opioids are particularly important today and will help to develop an adequate scheme of corrective effects to stabilize the morphofunctional condition of periodontium tissues.

The aim of the study was to determine the features of the submicroscopic organization of the structural components of the periodontium under the action of an opioid analgesic for two weeks and its four-week withdrawal in the experiment.

\section{Materials and methods}

The study was conducted on 22 adult rats-males of the Wistar line, weighing $160 \mathrm{~g}$, aged 4.5-6 months. Animals were divided into 2 groups. The first group included intact rats $(n=10)$. The second group included 12 animals, which were administered intramuscularly opioid analgesic nalbuphine daily for the first two weeks, based on the mean therapeutic dose for the rat, and considering the mean weight of the experimental group $(0.212 \mathrm{mg} / \mathrm{kg})$ and its subsequent 4 weeks. Controls were 3 male rats administered intramuscularly saline. Sampling was performed after 6 weeks of the experiment.

All animals were kept under standard vivarium conditions and all experiments were carried out in accordance with the provisions of the "European Convention for the Protection of Vertebrate Animals Used for Experimental and Other Scientific Purposes" (Strasbourg, 1985). Before sampling the biopsy material, the animals were primed with intraperitoneal administration of sodium thiopental $(25 \mathrm{mg} / \mathrm{kg})$.

For electron microscopic examination, pieces of soft periodontal tissue were used in the gums papilla. The tissue fragments were fixed in a $2.5 \%$ solution of glutaraldehyde and in a $1 \%$ solution of osmium tetroxide on phosphate buffer $\mathrm{pH}=7.2-7.4$, dehydrated in alcohols and propylene oxide and poured into a mixture of epoxy resins with araldite [24]. Ultra-thin sections were made on a UMPT3m ultramicrotome, which was counterstained with uranyl acetate and lead citrate and studied in a PEM-100-01 electron microscope.

\section{Results}

Electron microscopic studies have shown that the structural changes in the epithelium of the different sites studied were similar in nature, but not as significant as in the subgroup of animals without opioid withdrawal. The cells of the basal layer of the epithelial plate of its free part have an enlarged nucleus area, the karyoplasm of which includes the osmiophilic regions of heterochromatin, but they are located mainly near the nuclear envelope. Small, compact nucleolus are available. The karyolemma has

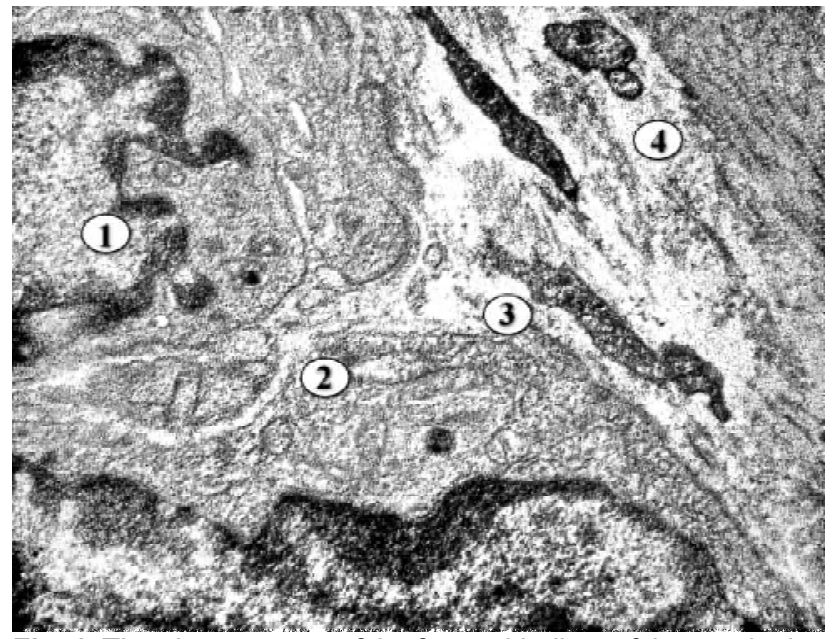

Fig. 1. The ultrastructure of the free epithelium of the rat gingiva after six weeks: two weeks of opioid administration and four weeks after its abolition. 1 - basal layer epitheliocyte nucleus, 2 cytoplasm of epitheliocyte, 3 - basement membrane, 4 - connective tissue. $\times 14000$.

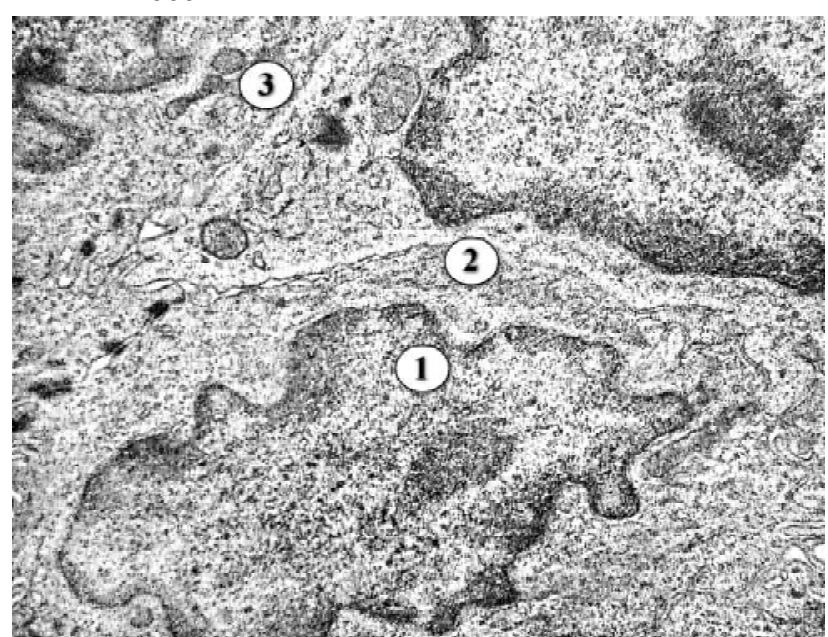

Fig. 2. Ultrastructure of the rat gingival sulcus epithelium after six weeks: two weeks of opioid administration and four weeks after its abolition. 1 - nucleus with invagination of karyolemma, 2 cytoplasm of epitheliocytes, 3 - desmosomes. $x 9000$.

shallow invaginations, and its perinuclear spaces are enlarged only in some places. In the cytoplasm there is a normalization of organelles, damaged ultrastructures are small in number. Part of the mitochondria has a focal electron-light matrix and partially damaged cristae. In the hyaloplasm, areas with poorly contoured tonofilaments were detected, some of them homogenized. Thick areas with fuzzy intercellular contacts (Fig. 1) are noted between plasmalemmas. The epitheliocytes of the spinosum and granulosum layers are also less altered, the structure of the nucleus and cytoplasm normalizing.

The nuclei have a shallow invagination of the karyolemma, euchromatin predominates in the karyoplasm. There are different sizes of cells in the granular layer, sometimes large clumps of keratohyalin. The desmosomal contacts are sometimes damaged. The 


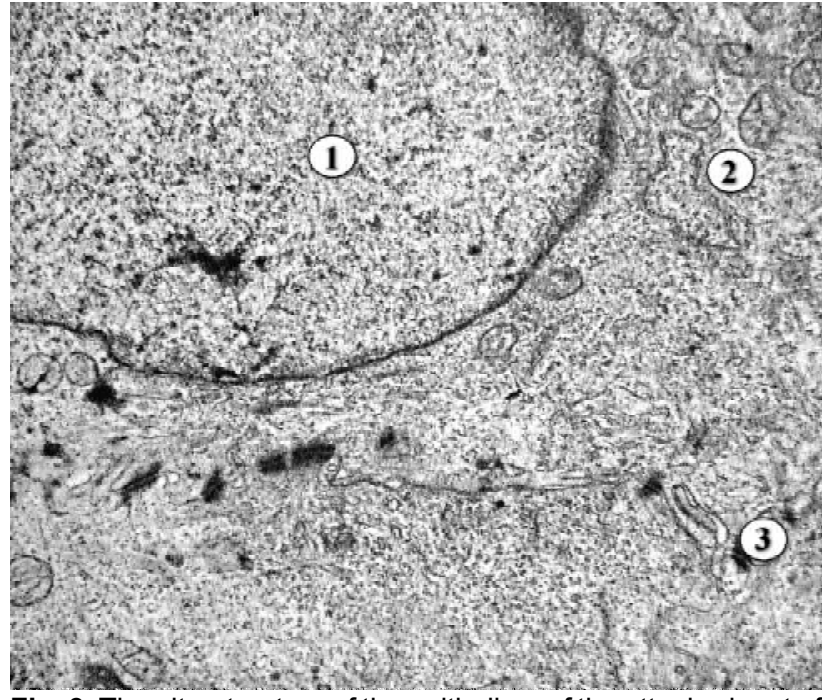

Fig. 3. The ultrastructure of the epithelium of the attached part of the rat gingiva is six weeks: two weeks of opioid administration and four weeks after its abolition. 1 - oblong nucleus, 2 mitochondria, 3 - plasmolemmas connected by desmosomes. x12000.

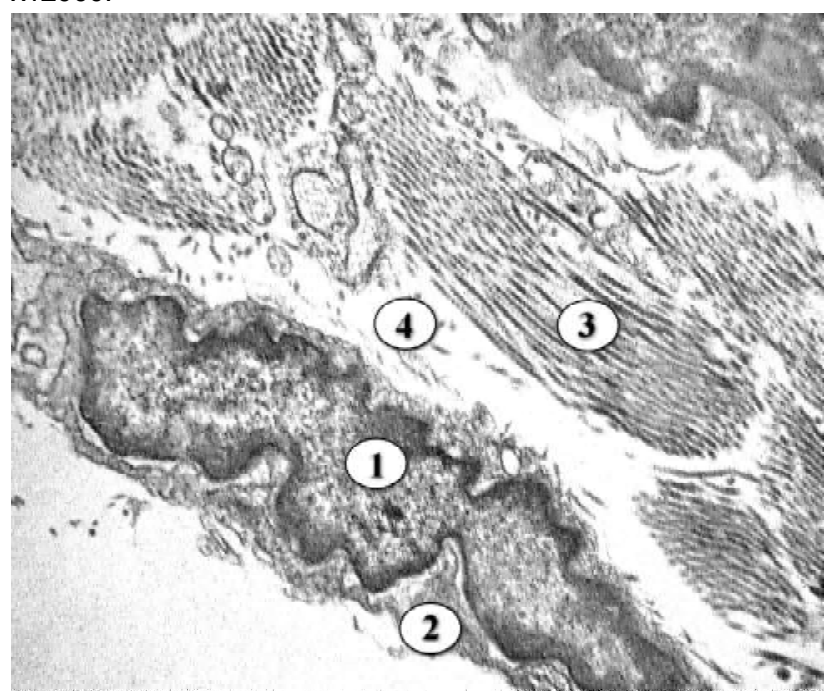

Fig. 4. The ultrastructure of the rat periodontium after six weeks: two weeks of opioid administration and four weeks after its abolition. 1 - fibrocyte nucleus, 2 - fibrocyte cytoplasm, 3 - collagen fibril bundle, 4 - light amorphous electron component. x14000.

ultrastructural organization of the gums epithelium of this group is also unchanged. There is no swelling of the cytoplasm of the epitheliocytes of the basal and spinosum layers. Only the nuclei of the superficial layers of cells have karyolemma invaginations, and the cytoplasm is virtually unchanged. Clear contours of plasmolemma and desmosomal contacts (Fig. 2). Submicroscopically, the epithelium of the attached part of the gums of the animals is found to be unaltered. Epitheliocytes include the oblongshaped nucleus with shallow invasions of the karyolemma, and euchromatin is noted in the karyoplasm. In the cytoplasm, there are small mitochondria, a few cristae. The clear contours of the plasmolemma, the intercellular contacts are osmiophilic, appear enlarged (Fig. 3).

Electron microscopic studies of the periodontium of animals have found that its structural components are unchanged. Collagen fibers are characterized by a tufted arrangement of fibrils, only in the superficial area they are partially stratified and moderate swelling of the amorphous component of the intercellular substance of the connective tissue is present. Fibroblasts of the usual structure, and some fibrocytes have irregular shape with invaginations of karyolemma of the nucleus and placement of heterochromatin on the periphery. The cytoplasm contains ribosomes, enlarged tubules of the granular endoplasmic reticulum, part of the mitochondria with the enlightened matrix (Fig. 4). Lymphocytes, neutrophils and macrophages are observed in connective tissue surrounding the periodontium. Ultrastructurally, the cytoplasm of the macrophage reveals lysosomes, a little phagosome, indicating little damage to the structures. Plasmolemma forms protrusion in the form of outgrowths and has the invaginations required for phagocytosis of damaged structures (Fig. 5).

Submicroscopic studies of the mucous membrane of the rats gums of this group found that moderate reactive changes are characteristic of the hemomicrocirculatory bed of the gums. The lumps of the blood capillaries are small, in them the formed elements of blood, mainly erythrocytes are found. The nucleus and cytoplasm of endothelial cells have their own structural organization. In the wide cytoplasmic areas of the cells, there are many foam pinocytosis vesicles, caveolae.

In the perinuclear part of the cytoplasm organelles are small in number. The tubules of the endoplasmic reticulum are moderately dilated, mitochondria with electron-light matrix and small cristae. The elongated nucleus is well contoured, the perinuclear spaces are small, and

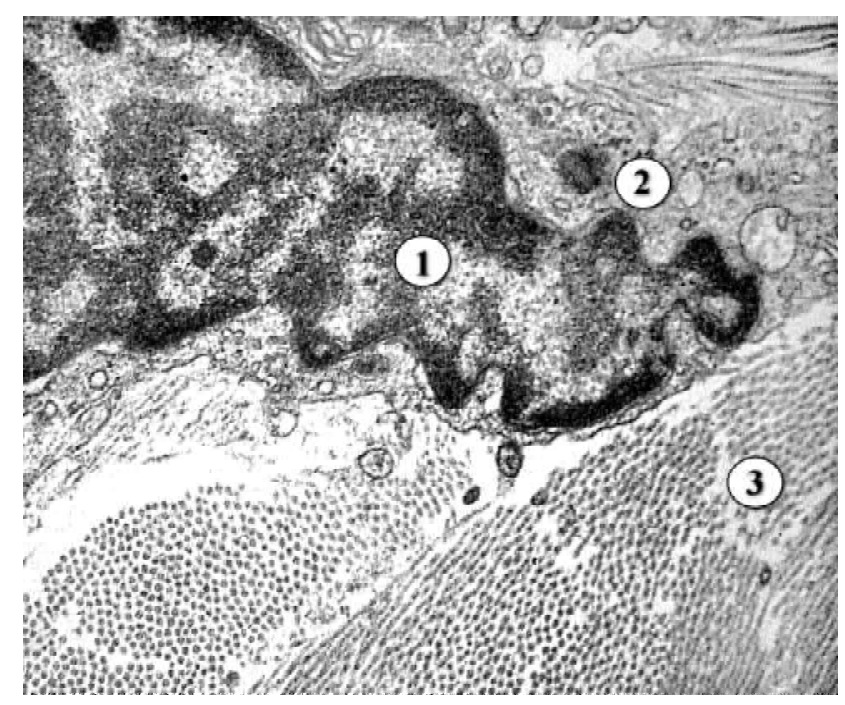

Fig. 5. The ultrastructure of the rat periodontal after six weeks: two weeks of opioid administration and four weeks after its abolition. 1 - macrophage nucleus, 2 - macrophage cytoplasm, 3 collagen fibril bundle. x14000. 


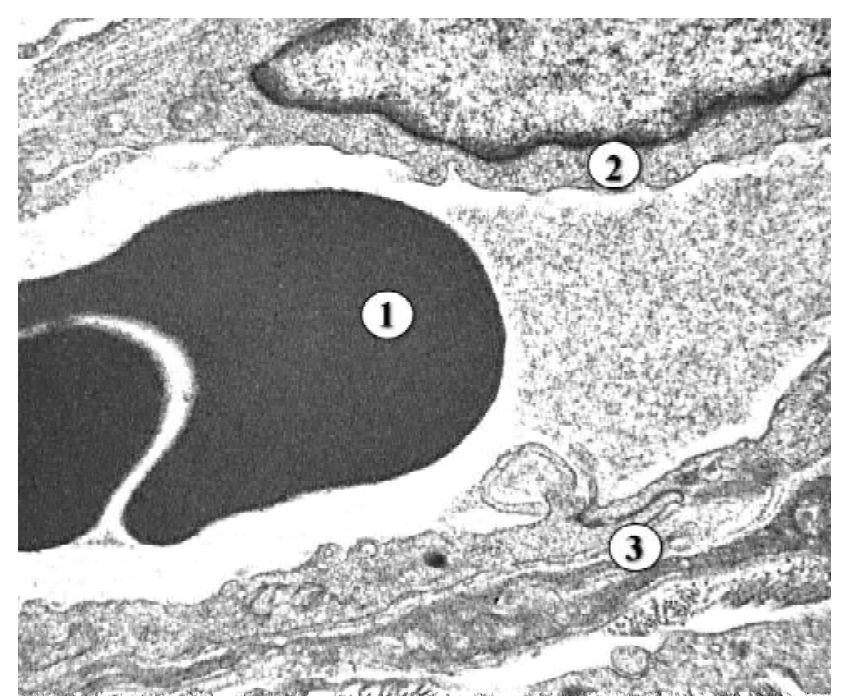

Fig. 6. The ultrastructure of the hemocapillary of the mucous membrane of the gingival mucosa of the rat after 6 weeks: two weeks of opioid administration and four weeks after its abolition. 1 - lumen with red blood cells, 2 - nucleus and cytoplasm of endothelial cells, 3 - basement membrane. x12000.

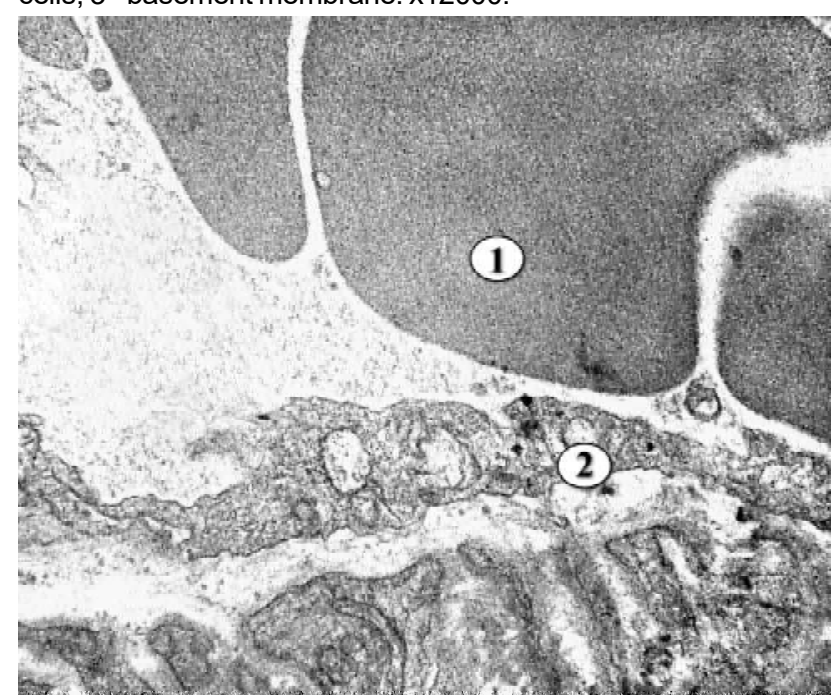

Fig. 7. Ultrastructure of the lamina propria venules of the mucous membrane of the rat gums after six weeks: two weeks opioid use and four weeks after its withdrawal. 1 - a lumen with erythrocytes, 2 - cytoplasm of endothelial cells. $x 14000$.

euchromatin prevails in the karyoplasm. The basal membrane is wide, wavy and has clear contours. Perivascular edema is insignificant; collagen fibers and an amorphous component are present in the loose connective tissue of the advent (Fig. 6). Venules have moderately blood-filled lumps, the cytoplasm of endothelial cells is preserved, however, here and there destructively altered mitochondria are present. Separate areas of the cytoplasm protrude into the lumen, which increases the area of interaction of endothelial cells with the internal contents of the vessel. The basal membrane is thickened, but is well contoured, the perivascular spaces are slightly enlarged (Fig. 7).

\section{Discussion}

In the modern professional literature there are more and more studies devoted to the study of the effect of opioid drugs on various organs and systems [1, 8, 12, 17, 22], but their effect on the structural organization of the of oral cavity and periodontium remains unknown [6, 10, 20, 21]. Scientific research is mainly aimed at studying the changes in the internal organs that develop as a result of the introduction of such classic opioids as morphine, tramadol and codeine using significantly high doses [4, 5, 8, 15]. In addition, studies on the effects of the opioid analgesic nalbuphine on tissues and organs of the oral cavity are virtually absent in the literature. Preferably, such studies have been performed to study the characteristics of pharmacodynamics and pharmacokinetics both in experiment and in volunteers [2, 11, 13].

As a result of our studies of the experimental effect of opioid for two weeks and its 4-week cancellation, we found no significant destructive changes in periodontium. However, the positive dynamics of regeneration of periodontal components at the ultrastructural level were also not observed. Submicroscopically, there are reactive changes, which are manifested by focal sites of expansion of perinuclear spaces, fuzzy intercellular contacts, partial damage of the cristae in the mitochondria of epitheliocytes and endothelial cells, as well as swelling of the intercellular substance and minor constituents of periodontium.

In the available medical literature there are no results of studies of the ultrastructural organization of periodontal tissues in dynamics at different terms of opioid exposure and after its abolition, which makes it impossible to perform a comparative analysis of the data obtained. Given the relevance of this problem, the study of periodontal tissues in drug addicts is insufficient and requires further scientific research $[5-7,16,21,25]$. Therefore, we believe that the method of creating a biological experimental model of opioid exposure will help to find out the peculiarities of submicroscopic organization in periodontal tissues, which is relevant and necessary in modern dentistry and periodontology.

Prospects for further research are to study the features of ultrastructural reorganization in periodontal tissues when exposed to opioid, after its abolition, and at the application of medical correction at an early date.

\section{Conclusions}

1. At the end of week 6 of the experiment, no irreversible changes in the ultrastructural organization of periodontal components were detected in the short-term effect of the opioid for two weeks and its subsequent cancellation of.

2. Submicroscopically, it was found that the abolition of opioid analgesic at longer periods (3-6 weeks) does not lead to complete restoration of the structural components of the periodontium, regenerative processes are slow, there are signs of reactive changes. 


\section{References}

[1]Alinejad, S., Kazemi, T., Zamani, N., Hoffman, R.S., Mehrpour, O. (2015). A systematic review of the cardiotoxicity of methadone. EXCLI J., 14, 577-600. doi: 10.17179/excli2015553.

[2] Attia, J. Z., Kamel, M. Y., Yousef, R. K. (2015). Safety of nalbuphine on neural tissues of rats and its efficacy in the treatment of acute herpetic pain in children with acute lymphoblastic leukemia. Res. Opin. Anesth. Intensive Care, 2, 89-95. doi: 10.4103/2356-9115.172801

[3] Avdeev, O. V. (2010). Structural changes of periodontal tissues in experiment. Bulletin of dentistry, 71(2), 2.

[4] Carnaval, T. G., Sampaio, R. M., Lanfredi, C. B., Borsatti, M. A., \& Adde, C. A. (2013). Effects of opioids on local anesthesia in the rat: a codeine and tramadol study. Braz. Oral. Res., 27(6), 455-462. doi: 10.1590/S1806-83242013000600003.

[5] Dolova, A. I. (2006). The use of the antioxidant of Mexidol in the complex treatment of chronic generalized periodontitis in patients suffering from opiate drug dependence (experimental clinical study). (Master's thesis). Moskva

[6] Fedun, I. R. (2019). Features of clinic and treatment of periodontal diseases in drug addicted patients. (Master's thesis). Danylo Halych National Medical University, Ministry of Health of Ukraine, Lviv.

[7] Fik, V. B., Paltov, E. V., \& Kryvko, Y. Y. (2018). Morphofunctional peculiarities of the periodontal tissue under conditions of simulated eight-week opioid effect. Deutscher Wissenschaftscherold German Science Herald, 1, 14-17. doi: 10.19221/201814

[8] Ghoneim, F. M., Khalaf, H. A., Elsamanoudy, A. Z., \& Helaly, A. N. (2014). Effect of chronic usage of tramadol on motor cerebral cortex and testicular tissues of adult male albino rats and the effect of its withdrawal: histological, immunohistochemical and biochemical study. Int. J. Clin. Exp. Pathol., 7, 73237341. PMID: 25550769 PMCID: PMC4270590

[9] Hasturk, H., \& Kantarci, A. (2015). Activation and resolution of periodontal inflammation and its systemic impact. Periodontol. 2000, 69(1), 255-273. doi:10.1111/prd.12105

[10] Kayal, R. A., Elias, W. Y., Alharthi, K. J., Demyati, A. K., \& Mandurah, J. M. (2014). Illicit drug abuse affects periodontal health status. Saudi Med. J., 35(7), 724-728. PMID: 25028230

[11] Liaqat, N., \& Dar, S. H. (2017). Comparison of single-dose nalbuphine versus tramadol for postoperative pain management in children: a randomized, controlled trial. Korean J. Anesthesiol, 70, 184-187. doi: 10.4097/kjae.2017.70.2.184

[12] Mallappallil, M., Sabu, J., Friedman, E. A., \& Salifu, M. (2017). What Do We Know about Opioids and the Kidney? Int. J. Mol. Sci., 18(1), 223. https://doi.org/10.3390/ijms18010223

[13] Mello, N. K., Mendelson, J. H., Sholar, M. B., Jaszyna-Gasior, M., Goletiani, N., \& Siegel, A. J. (2005). Effects of the mixed $\mathrm{mu} /$ kappa opioid nalbuphine on cocaine-induced changes in subjective and cardiovascular responses in men. Neuropsychopharmacology, 30(3), 618-632. doi: 10.1038/ sj.npp.1300631

[14] Nagpal, R., Yamashiro, Y., \& Izumi, Y. (2015). The two-way association of periodontal infection with systemic disorders: an overview. Mediators Inflamm. 2015:793898. doi: 10.1155/ 2015/793898

[15] Pacheco, C. M. F., Queiroz-Junior, C. M., Maltos, K. L. M., Calliari, M. V., Rocha, O. A., \& Francischi, J. N. (2007). Local opioids in a model of periodontal disease in rats. Archives of Oral Biology, 52(7), 677-683. doi: 10.1016/ j.archoralbio.2006.12.012

[16] Patalakha, O. V. (2019). Features of the immune response and optimization of treatment of generalized periodontitis in patients with toxic opioid hepatitis. (Master's thesis). State Institution "I.I. Mechnikov Institute of Microbiology and Immunology of the National Academy of Medical Science of Ukraine", Kharkiv.

[17] Radke, J. B., Owen, K. P., Sutter, M. E., Ford, J. B., \& Albertson, T. E. (2014). The effects of opioids on the lung. Clin. Rev. Allergy Immunol., 46, 54-64. doi: 10.1007/s12016-013-8373$\mathrm{z}$

[18] Ranjan, R., Abhinay, A., \& Mishra, M. (2018). Can oral microbial infections be a risk factor for neurodegeneration? A review of the literature. Neurol. India, 66, 344-351. doi: 10.4103/00283886.227315

[19] Rosier, B. T., de Jager, M., Zaura, E., \& Krom, B. P. (2014). Historical and contemporary hypotheses on the development of oral diseases: are we there yet? Front Cell Infect. Microbiol., 4, 92. doi: 10.3389/fcimb.2014.00092

[20] Rotemberg, E., Salveraglio, I., Kreiner, M., Piovesan, S., Smaisik, K., Ormaechea, R., \& Varela, A. (2015). Estado dental y periodontal de poblacion en tratamiento por consumo de drogas: Estudio piloto. Rev. Odontoestomatologia, 17(25), 3439. http://www.scielo.edu.uy/scielo.php.

[21] Saini, G. K., Gupta, N. D., \& Prabhat, K. C. (2013). Drug addiction and periodontal diseases. J. Indian Soc. Periodontol., 17, 587-591. doi: 10.4103/0972-124X.119277.

[22] Seltenhammer, M. H., Marchart, K., Paula, P., Kordina, N., Klupp, N., Schneider, B. ... Risser, D. U. (2013). Micromorphological changes in cardiac tissue of drug-related deaths with emphasis on chronic illicit opioid abuse. Addiction, 108(7), 1287-1295. doi: $10.1111 /$ add. 12106

[23] Shekarchizadeh, H., Khami, M.R., Mohebbi, S. Z., Ekhtiari, H., \& Virtanen, J. I. (2013). Oral health of drug abusers: A review of health effects and care. Iran J. Public Health, 42(9), 929-40. PMCID: PMC4453891 PMID: 26060654

[24] Stempak, J. G., \& Ward, R. T. (1964). An improved staining method for electron microscopy. J. Cell. Biol., 22(3), 697701. doi: 10.1083/jcb.22.3.697

[25] Sun, D., Ye, T., Ren, P., \& Yu, S. (2018). Prevalence and etiology of oral diseases in drug-addicted populations: a systematic review. Int. J. Clin. Exp. Med., 11(7), 6521-6531 www.jjcem.com/ISSN:1940-5901/IJCEM0075796

[26] Vinogradova, O. M., \& Shkrebniuk, R. Yu. (2015). Differential methods of treatment of periodontal tissue diseases on the background of diabetes. Clinical and experimental pathology, 51(1),205-208. http://nbuv.gov.ua/UJRN/kep_2015_14_149

\section{ЕЛЕКТРОННО-МІКРОСКОПІЧНІ ДОСЛІДЖЕННЯ ПАРОДОНТУ ПРИ ЕКСПЕРИМЕНТАЛЬНІЙ ДВОТИЖНЕВІЙ ДІЇ ОПІОЇДУ ТА ПІСЛЯ ЙОГО ВІДМІНИ ВПРОДОВЖ ЧОТИРЬОХ ТИЖНІВ}

\section{Фік В.Б., Пальтов Є.В., Кривко Ю.Я.}

Зважаючи на шкідливий вплив опіоїдних речовин при неконтрольованому їх вживанні, неможливо легковажити ранніми проявами ушкоджень тканин і органів ротової порожнини, що складає актуальну проблему сьогодення. Метою цієї роботи було дослідити особливості субмікроскопічної організації структурних компонентів пародонту при дії опіоїдного аналгетика впродовж двох тижнів та його 4-тижневої відміни в експерименті. Дослідження проведено на 22 статевозрілих щурах- 
самиях лінії Wistar, масою 160 г, віком 4,5-6 місяців. Тваринам протягом перших двох тижнів вводили щоденно внутрішньом'язово одноразово опіоїдний аналгетик налбуфрін у перерахунку середньої терапевтичної дози для щура, а також з урахуванням середньої ваги піддослідної групи (0,212 мг/кг) та його подальшою відміною протягом наступних 4 тижнів. Для електронно-мікроскопічного дослідження використали фрагменти м'яких тканин пародонту. Субмікроскопічно виражених деструктивних змін у тканинах пародонту виявлено не було. Позитивної динаміки регенерації компонентів пародонту на ультраструктурному рівні також не виявили. В цитоплазмі клітин епітелію вільної частини ясен спостерігали деструкцію органел, частково ушкоджені кристи мітохондрій, погано контурувались тонофріламенти, встановлені неглибокі інвагінації каріолеми, між плазмолемами спостерігали потовщені ділянки та пошкоджені десмосомальні контакти. У поверхневих ділянках періодонту колагенові волокна були частково розшарованими, спостерігали помірний набряк міжклітинної речовини сполучної тканини, у частини фріброцитів встановлені інвагінації каріолеми ядра та розміщення гетерохроматину по периферії. Ультраструктурно у цитоплазмі макрофрага відмічено лізосоми, фрагосом небагато, що свідчить про незначне ушкодження структур. У просвітах кровоносних капілярів виявляються фоорменні елементи крові, переважно еритроцити, в перинуклеарній частині цитоплазми органел небагато, мітохондрії з електронно світлим матриксом та невеликими кристами, периваскулярний набряк незначний, у цитоплазмі ендотеліоцитів венул спостерігались деструктивно змінені мітохондрії, базальна мембрана потовщена, периваскулярні простори збільшені. Таким чином, наприкінці 6 тижня експерименту при короткотривалій дії опіоїду впродовж двох тижнів та його подальшій 4-тижневій відміні глибоких незворотніх змін ультраструктурної організації компонентів пародонту не виявлено. Слід відмітити, що повного відновлення структурних компонентів пародонту не спостерігається, наявні ознаки реактивних змін, репаративні процеси сповільнені.

Ключові слова: пародонт, опіоїд, відміна опіоїду, ультраструктура, експеримент.

\section{ЭЛЕКТРОННО-МИКРОСКОПИЧЕСКИЕ ИССЛЕДОВАНИЯ ПАРОДОНТА ПРИ ЭКСПЕРИМЕНТАЛЬНОМ ДВУХНЕДЕЛЬНОМ ВЛИЯНИИ ОПИОИДА И ПОСЛЕ ЕГО ОТМЕНЫ В ТЕЧЕНИЕ ЧЕТЫРЕХ НЕДЕЛЬ \\ Фик В.Б., Пальтов Е.В., Кривко Ю.Я.}

Учитывая вредное воздействие опиоидных веществ при неконтролируемом их употреблении, невозможно пренебрегать ранними проявлениями повреждений тканей и органов ротовой полости, что составляет актуальную проблему современности. Целью работы было исследовать особенности субмикроскопической организации структурных компонентов пародонта при действии опиоидного анальгетика в течение двух недель и после его 4-недельной отмены в эксперименте. Исследование проведено на 22 половозрелых крысах-самцах линии Wistar, массой 160 г, в возрасте 4,5-6 месяцев. Животным в течение первых двух недель вводили ежедневно внутримышечно однократно опиоидный анальгетик налбуфин в перерасчете средней терапевтической дозы для крысы, а также с учетом среднего веса подопытной группы (0,212 мг/кг) и его последующей отменой в течение следующих 4 недель. Для электронно-микроскопического исследования использовали фррагменты мягких тканей пародонта. Субмикроскопически выраженных деструктивных изменений в тканях пародонта выявлено не было. Положительной динамики регенерации компонентов пародонта на ультраструктурном уровне также не выявили. В цитоплазме клеток эпителия свободной части десны наблюдали деструкцию органелл, частично поврежденные кристы митохондрий, плохо контурировались тонофиламенты, установлены неглубокие инвагинации кариолеммы, между плазмолеммами наблюдали утолщенные участки и поврежденные десмосомальные контакты. $B$ поверхностных участках периодонта коллагеновые волокна были частично расслоенными, наблюдали умеренный отек межклеточного вещества соединительной ткани, у части фриброцитов установлены инвагинации кариолеммы и наличие гетерохроматина на периферии. Ультраструктурно в цитоплазме макрофага отмечены лизосомы, фрагосом немного, что свидетельствует о незначительном повреждении структур. В просветах кровеносных капилляров выявляются форменные элементы крови, преимущественно эритроциты, в перинуклеарной части цитоплазмы органелл немного, митохондрии с электронно светлым матриксом и небольшими кристами, периваскулярный отек незначительный, в цитоплазме эндотелиоцитов венул наблюдаются деструктивно измененные митохондрии, базальная мембрана утолщена, периваскулярные пространства увеличены. Таким образом, в конце 6 недели эксперимента при кратковременном действии опиоида в течение двух недель и его дальнейшей 4-недельной отмене, глубоких необратимых изменений ультраструктурной организации компонентов пародонта не обнаружено. Следует отметить, что полного восстановления структурных компонентов пародонта не наблюдается, в наличии явные признаки реактивных изменений и замедленные репаративные процессы.

Ключевые слова: пародонт, опиоид, отмена опиоида, ультраструктура, эксперимент. 